\title{
Zonula Adherens
}

National Cancer Institute

\section{Source}

National Cancer Institute. Zonula Adherens. NCI Thesaurus. Code C13736.

The best understood cell-cell junction required for adhesion between cells in the epithelium. It seals adjacent epithelial cells together, preventing the passage of most dissolved molecules from one side of the epithelial sheet to the other. Adherens junctions are located most apically in insect cells and just basal to the tight junction in vertebrate cells. It is formed by the fusion of adjacent cell membranes which encircle the apical cell surface like a belt or fence based on homophilic association between molecules of the transmembrane protein $\mathrm{E}$-cadherin, which is linked on its cytoplasmic side to the actin cytoskeleton via b-catenin (Drosophila Armadillo) and a-catenin. The adherens junctions and associated cytoskeleton form a continuous band (zonula adherens) around the apical circumference of each cell, thus uniting the cells of the epithelium into a coherent sheet. 